\title{
Effect of broiler slaughter weight on meat yield and quality
}

\author{
Aleksandra Nikolic ${ }^{*}$, Milijana Babic², Jelena Jovanovic ${ }^{1}$, Nikola Cobanovic ${ }^{2}$, Ivana Brankovic Lazic', \\ Lazar Milojevic ${ }^{l}$, Nenad Parunovic ${ }^{l}$
}

A b s tr a c t: Broiler meat quality depends on the interaction of several factors, including genotype, slaughter age/body weight, pre-slaughter handling, and slaughter method. The aim of this study was to determine the effect of slaughter weight on meat yield and quality of broilers. The material consisted of 42 broilers, classified into three groups: lighter $(<2500 \mathrm{~g})$, medium (2500-3000 g) and heavier (>3000 g). The following meat yield parameters were measured: cold carcass weight, breast weight before and after deboning, breast skin and bone weights, thigh weight before and after deboning, thigh skin and bone weights, drumstick weight before and after deboning, and drumstick skin and bone weights. Meat pH (M. pectoralis major) and instrumental colour (breast and drumstick) were measured 24 h post-mortem. Meat quality classes (pale, soft and exudative and normal meat) were determined based on breast muscle $L^{*}$ value. Heavier broilers had higher $(P<0.05)$ cold carcass weight, breast, thigh and drumstick weights both before and after deboning compared to medium and lighter broilers. In contrast, meat quality traits were not significantly $(P>0.05)$ affected by slaughter weight. In conclusion, production of heavy broilers had a beneficial effect on meat quantity, while the effect of slaughter weight on meat quality was negligible.

Keywords: heavier broiler, meat yield, meat quality, instrumental color.

\section{Introduction}

Modern livestock production aims to produce animals with high meatiness and good meat quality traits at the same time with minimum production cost (Adzitey and Nurul, 2011). These have been achieved through genetic manipulation of animals and careful breeding, which has led to a considerable increase in stress susceptibility, decrease in resistance to diseases and impaired meat quality (Adzitey and Nurul, 2011; Cobanovic et al., 2019). In recent years, the worldwide, high demand for broiler meat has resulted in pressure on breeders and nutritionists to increase the growth rate, feed efficiency, and breast muscle size and to reduce the amount of abdominal fat (Toldrá and Reig, 2011; Glamoclija et al., 2017). It is believed that the genetic progress of broiler growth leads to stress, resulting in histological and biochemical modifications of the muscle tissue, which have negative effects on meat quality. The latest concerns about broiler meat quality are associated with deep pectoral muscle disease and white striping, which disrupt the appearance of the product and increases the problem of the meat's poor ability to retain water during processing and storage as a result of the occurrence of pale, soft and exudative (PSE) meat (Barbut et al., 2008). This meat appearance and loss of protein quality are attributed to the denaturation of proteins caused by an excessively fast $\mathrm{pH}$ drop in combination with high muscle temperature within 30 minutes after slaughter (Massimiliano and Claudio, 2012). Broiler meat quality depends on the interaction of several factors, including genotype, slaughter age/body weight, pre-slaughter handling, and slaughter method (Warris, 2010; Raseta et al., 2017). The high demand for raw cuts and processed products has led to the production of very heavy broilers (Baéza et al., 2012). Some authors found that broiler slaughter weight affects meat quality traits (Bianchi et al., 2007; Janisch et al., 2011; Baéza et al., 2012; Yalçin and Güler, 2012; Yalçin et al., 2014). Therefore, the aim of this study was to determine the effect of slaughter weight on meat yield and quality of broilers. 


\section{Materials and methods}

The study was conducted during summer of 2018 on 42 male Cobb broilers (about 42 days old, with an average live weight of $2805 \pm 558.1 \mathrm{~g}$ ) slaughtered at the same abattoir. All the broilers were reared on the same commercial farm under identical conditions. The treatment conditions, both before and after slaughter, were identical for all broilers and in accordance with the conventional industrial practice.

\section{Meat yield parameters}

Each carcass was weighed immediately after chilling to obtain cold carcass weight. Thereafter, each carcass (including skin and bone) was manually cut using a knife into different commercial cuts, which were breast, thighs, and drumsticks. The different commercial cuts were first weighed to determine breast, thigh and drumstick weights before deboning. Then, breast, thighs and drumsticks were further deskinned and deboned into meat, bone and skin. The breast, thighs and drumsticks were re-weighed to obtain breast, thigh and drumstick weights after deboning. Afterwards, the bones and skin of the three commercial cuts were weighted separately to determine breast skin and bone weights, thigh skin and bone weights, and drumstick skin and bone weights. All cutting, deskinning and deboning were performed by the same personnel. An electronic scale with a high sensitivity was used for weighing (Ard 110 Adventurer, Ohaus-USA).

\section{Meat quality parameters}

At $24 \mathrm{~h}$ post-mortem, breast muscle $\mathrm{pH}$ was directly measured using a $\mathrm{pH}$ meter (Cyber Scan pH 510, EUTECH-Netherlands) with a thin penetrating needle inserted in the centre of the M. pectoralis major, 0.5 to $1.0 \mathrm{~cm}$ below the muscle surface. The $\mathrm{pH}$ meter was calibrated with $\mathrm{pH} 4.00$ and 7.00 phosphate buffer before each series of measurements and the electrode was rinsed with distilled water between each measurement. The $\mathrm{pH}$ values were measured in triplicate, and the average of the three measurements was taken as the final result.

Instrumental colour (Commission Internationale de l'Eclairage [CIE] L*a*b*) (CIE, 1976) was measured on the carcass surface over the breast and drumstick muscles using a Konica-Minolta portable Chroma Meter (CR 410, Minolta, Osaka, Japan) equipped with a $25 \mathrm{~mm}$ aperture, $0^{\circ}$ viewing angle, and D65 illuminant. Before each series of measurements, the instrument was calibrated using a white ceramic tile. Breasts and drumsticks were exposed to air for at least $30 \mathrm{~min}$ at $15^{\circ} \mathrm{C}$ before colour measurement. Lightness $\left(\mathrm{L}^{*}\right)$, redness $\left(\mathrm{a}^{*}\right)$, and yellowness $\left(b^{*}\right)$ values were determined on the each meat cut at three sites free of any discoloration: the proximal extremity of the muscle, the distal extremity, and between the proximal and distal extremities, and the average value for each meat cut was calculated. Meat quality classes were determined based on breast muscle $L^{*}$ value and placed into one of two categories: meat cuts were classified as PSE when their $\mathrm{L}^{*}$ value was equal or higher than 58 , while meat cuts were classified as normal meat when their $\mathrm{L}^{*}$ value was lower than 58 (Karunanayaka et al., 2016).

\section{Statistical analysis}

Statistical analyses of the results were conducted using software GraphPad Prism version 7.0 for Windows (GraphPad Software, San Diego CA, USA, www.graphpad.com). Broilers were divided into three weight groups: broilers with a live weight lower than $2500 \mathrm{~g}$ (lighter broilers) $(\mathrm{n}=20)$; broilers with a live weight between 2500 and $3000 \mathrm{~g}$ (medium broilers) $(\mathrm{n}=15)$; and broilers with a live weight higher than $3000 \mathrm{~g}$ (heavier broilers) $(\mathrm{n}=7)$. One-way ANOVA with Tukey's post-hoc test was performed to test the effect of slaughter weight on meat yield and quality of broilers. Data were described by descriptive statistical parameters as the mean value and standard error of the mean (SEM). Also, Pearson correlation analysis was run between the slaughter weight and meat yield and quality parameters to numerically summarise the degree of association between any two variables. The Chi-squared test was used to determine the incidence of meat quality classes with respect to the slaughter weight. Values of $P<0.05$ were considered significant.

\section{Results and discussion}

Effects of slaughter weight on meat yield parameters of broilers are reported in Table 1. From this table, it is evident that heavier broilers had higher $(P<0.05)$ cold carcass weight, and breast, thigh and drumstick weights both before and after deboning in comparison with medium and lighter broilers. These results are supported because in this investigation the increase in slaughter weight resulted in increased $(P<0.05)$ cold carcass weight $(\mathrm{r}=1.000)$, breast weight before $(\mathrm{r}=0.8716)$ and after deboning $(r=0.9406)$, thigh weight before $(r=0.7805)$ and after deboning ( $\mathrm{r}=0.8199)$, and drumstick weight before $(\mathrm{r}=0.7830)$ and after deboning $(\mathrm{r}=0.8196)$ (Table 2$)$. 
Similar results were reported by other authors (Cahaner et al., 1986; Brake et al., 1993; Renema et al., 1999; Omojola et al., 2004), who found direct proportion between the weights of primal cuts (breast, thigh and drumstick) and broiler slaughter weight.

In contrast, there were no significant differences between broilers of different slaughter weights with respect to breast skin and bone weights, thigh skin weight, and drumstick skin weight $(P>0.05$; Table 2). The characteristics of superior carcasses are the maximum proportion of most valuable muscles (i.e. breast and thigh muscles), the minimum proportion of bone and the optimum proportion of fat (Eltrafi, 2006), which were the properties of carcasses obtained from heavier broilers. These results indicate that heavier broilers have better meat/bone ratio than medium and lighter broilers. Accordingly,

Table 1. Effects of slaughter weight on meat yield parameters of broilers $(n=42)$

\begin{tabular}{lcccccc}
\hline Parameters & Heavier & Medium & Lighter & SEM & $P$-value & Significance \\
\hline Number of animals & 7 & 15 & 20 & & & \\
Cold carcass weight (g) & $2414.00^{\mathrm{a}}$ & $1934.00^{\mathrm{b}}$ & $1628.00^{\mathrm{c}}$ & 70.822 & $<0.0001$ & $*$ \\
Breast weight before deboning (g) & $916.50^{\mathrm{a}}$ & $733.60^{\mathrm{b}}$ & $629.10^{\mathrm{c}}$ & 43.431 & $<0.0001$ & $*$ \\
Breast weight after deboning (g) & $735.20^{\mathrm{a}}$ & $583.30^{\mathrm{b}}$ & $474.50^{\mathrm{c}}$ & 35.835 & $<0.0001$ & $*$ \\
Breast skin weight (g) & 57.59 & 57.00 & 48.20 & 7.187 & 0.1321 & $\mathrm{~ns}$ \\
Breast bone weight (g) & 122.00 & 94.72 & 97.70 & 14.396 & 0.1006 & $\mathrm{~ns}$ \\
Thigh weight before deboning (g) & $360.30^{\mathrm{a}}$ & $295.00^{\mathrm{b}}$ & $251.20^{\mathrm{c}}$ & 23.046 & $<0.0001$ & $*$ \\
Thigh weight after deboning (g) & $249.10^{\mathrm{a}}$ & $207.30^{\mathrm{b}}$ & $169.90^{\mathrm{c}}$ & 15.048 & $<0.0001$ & $*$ \\
Thigh skin weight $(\mathrm{g})$ & 36.34 & 30.11 & 30.75 & 4.651 & 0.3040 & $\mathrm{~ns}$ \\
Thigh bone weight $(\mathrm{g})$ & $74.46^{\mathrm{a}}$ & $60.59^{\mathrm{b}}$ & $51.09^{\mathrm{b}}$ & 6.046 & $<0.0002$ & $*$ \\
Drumstick weight before deboning (g) & $306.50^{\mathrm{a}}$ & $238.80^{\mathrm{b}}$ & $216.30^{\mathrm{b}}$ & 15.913 & $<0.0001$ & $*$ \\
Drumstick weight after deboning $(\mathrm{g})$ & $190.70^{\mathrm{a}}$ & $145.00^{\mathrm{b}}$ & $128.90^{\mathrm{c}}$ & 9.092 & $<0.0001$ & $*$ \\
Drumstick skin weight $(\mathrm{g})$ & 25.94 & 24.06 & 20.65 & 2.851 & 0.0633 & $\mathrm{~ns}$ \\
Drumstick bone weight $(\mathrm{g})$ & $93.40^{\mathrm{a}}$ & $73.87^{\mathrm{b}}$ & $71.03^{\mathrm{b}}$ & 6.962 & 0.0022 & $*$ \\
\hline
\end{tabular}

Legend: * Statistical significance at $(P<0.05)$; ns: not significant $(P>0.05)$; - Different letters in the same row indicate a significant difference at $P<0.05{ }^{\left({ }^{\mathrm{a}} \mathrm{c}\right.} \mathrm{c}$

Table 2. Correlations ( $\mathrm{r}$ ) between slaughter weight and meat yield parameters.

\begin{tabular}{lc}
\hline Parameters & Slaughter weight \\
\hline Meat yield parameters & \\
Cold carcass weight $(\mathrm{g})$ & $1.0000^{*}$ \\
Breast weight before deboning (g) & $0.8716^{*}$ \\
Breast weight after deboning (g) & $0.9406^{*}$ \\
Breast skin weight (g) & $0.4489^{*}$ \\
Breast bone weight $(\mathrm{g})$ & $0.2723^{*}$ \\
Thigh weight before deboning (g) & $0.7805^{*}$ \\
Thigh weight after deboning $(\mathrm{g})$ & $0.8199^{*}$ \\
Thigh skin weight $(\mathrm{g})$ & $0.3213^{*}$ \\
Thigh bone weight $(\mathrm{g})$ & $0.6511^{*}$ \\
Drumstick weight before deboning $(\mathrm{g})$ & $0.7830^{*}$ \\
Drumstick weight after deboning $(\mathrm{g})$ & $0.8196^{*}$ \\
Drumstick skin weight $(\mathrm{g})$ & $0.4400^{*}$ \\
Drumstick bone weight $(\mathrm{g})$ & $0.5400^{*}$ \\
\hline
\end{tabular}

*Statistical significance at $(P<0.05)$. 
the highest carcass quality was obtained from broilers slaughtered at heavier weights.

In this study, breast bone weight $(\mathrm{r}=0.2723)$, thigh bone weight $(\mathrm{r}=0.6511)$ and drumstick bone weight $(\mathrm{r}=0.5400)$ increased linearly $(P<0.05)$ as the slaughter weight of the broiler increased (Table 2). This could be attributed to the fact that the increase in the slaughter weight, as a result of increase in breast and leg muscles, must also be accompanied by an increase in bone strength in the legs to ensure good health of the broilers (Eltrafi, 2006).
Effects of slaughter weight on meat quality parameters of broilers are reported in Table 3. None of the examined meat quality parameters was significantly $(\mathrm{P}>0.05)$ affected by slaughter weight. The high prevalence of PSE meat in each slaughter weight group recorded in this study (Table 3) could be explained by the fact that the experiment was conducted during the summer. It is well known that broilers, independent of slaughter weight, are extremely sensitive to high environmental temperature and relative humidity (Oba et al., 2009; Simoes et al., 2009; Langer et al., 2010; Carvalho et al.,

Table 3. Effects of slaughter weight on meat quality parameters in broilers $(n=42)$

\begin{tabular}{lcccccc}
\hline Parameters & Heavier & Medium & Lighter & SEM & $P$-value & Significance \\
\hline Number of animals & 7 & 15 & 20 & & & \\
pH value & 6.19 & 6.27 & 6.24 & 0.098 & 0.6624 & $\mathrm{~ns}$ \\
Breast muscle L* value & 58.47 & 56.47 & 57.97 & 1.819 & 0.2660 & $\mathrm{~ns}$ \\
Breast muscle a* value & 2.96 & 2.20 & 2.03 & 0.673 & 0.2810 & $\mathrm{~ns}$ \\
Breast muscle b* value & 7.34 & 7.60 & 7.01 & 1.486 & 0.8375 & $\mathrm{~ns}$ \\
Thigh muscle L* value & 54.31 & 56.42 & 56.97 & 1.618 & 0.1748 & $\mathrm{~ns}$ \\
Thigh muscle a* value & 7.71 & 6.05 & 4.90 & 1.729 & 0.1700 & $\mathrm{~ns}$ \\
Thigh muscle b* value & 8.79 & 8.71 & 8.19 & 1.464 & 0.8232 & $\mathrm{~ns}$ \\
Drumstick muscle L* value & 56.58 & 57.41 & 58.82 & 1.830 & 0.2943 & $\mathrm{~ns}$ \\
Drumstick muscle a* value & 5.88 & 7.15 & 6.85 & 1.434 & 0.6173 & $\mathrm{~ns}$ \\
Drumstick muscle b* value & 8.96 & 9.22 & 8.04 & 1.230 & 0.9743 & $\mathrm{~ns}$ \\
Meat quality classes & & & & & & \\
Normal meat (\%) & 42.86 & 66.67 & 55.00 & & 0.5553 & $\mathrm{~ns}$ \\
Pale, soft, exudative meat (\%) & 57.14 & 33.33 & 45.00 & & 0.5553 & $\mathrm{~ns}$ \\
\hline
\end{tabular}

Legend: Normal meat: $\mathrm{L}^{*} \leq 58$; Pale, soft, exudative: $\mathrm{L} *>58$; Statistical significance at $(P<0.05)$; ns: not significant $(P>0.05)$; - Different letters in the same row indicate a significant difference at $P<0.05$

Table 4. Correlations (r) between slaughter weight and meat quality parameters.

\begin{tabular}{lc}
\hline Parameters & Slaughter weight \\
\hline Meat quality parameters & \\
pH value & $-0.007^{1}$ \\
Breast muscle L* value & 0.0626 \\
Breast muscle a* value & 0.2360 \\
Breast muscle $\mathrm{b}^{*}$ value & 0.1204 \\
Thigh muscle L* value & $-0.229^{1}$ \\
Thigh muscle a* value & $0.3201^{*}$ \\
Thigh muscle $\mathrm{b}^{*}$ value & 0.0248 \\
Drumstick muscle L* value & $-0.180^{7}$ \\
Drumstick muscle a* value & 0.0051 \\
Drumstick muscle $\mathrm{b}^{*}$ value & 0.1798 \\
\hline
\end{tabular}

*Statistical significance at $(P<0.05)$. 
2014; Deshani et al., 2016). Therefore, the high occurrence of PSE meat in broilers recorded in this investigation is most likely the result of the combined effects of high environmental temperatures and relative humidity, which resulted in a greater degree of post-mortem glycolytic metabolism and low breast muscle pH in broilers (Fraqueza et al., 2006; Bianchi et al., 2007; Yalçin and Güler, 2012; Yalçin et al., 2014). Contrary to the results of this study, several studies (Lu et al., 2007; Simoes et al., 2009) have shown that heavier broilers are more susceptible to the deleterious effects of higher environmental temperatures and relative humidity. This could be explained by the fact that both heart and lung size decreases as a percentage of body weight with increasing growth rate, which likely affects the ability of heavier broilers to meet the respiratory demands of their bodies under high environmental temperature and relative humidity, and could contribute to the increased occurrence of panting, PSE meat and mortality (Baéza et al., 2012).

In this study, the increase in slaughter weight resulted in increased thigh muscle $\mathrm{a}^{*}$ value $(\mathrm{r}=0.3201$; $P<0.05)$. Meat colour depends on the haem pigment (myoglobin and haemoglobin) concentration, chemical states associated with the myoglobin oxygenation and oxidation processes and the amount of light reflected from the meat (Abdullah and Matarneh, 2010). Earlier studies reported that slaughter weight and age of broilers are the main factors affecting the meat colour, because myoglobin concentration increases with increasing age and body weight, shifting the meat colour toward a darker and redder colour, so heavier broilers produce darker breast meat (Abdullah and Matarneh, 2010; Baéza et al., 2012).

\section{Conclusions}

The results of this study showed that production of heavy broilers had a beneficial effect on meat quantity, because such animals provide large amounts of meat presenting with characteristics appropriate for further processing. On the other hand, the effect of slaughter weight on meat quality was negligible. Therefore, further investigation taking into account different pre-slaughter conditions is required to clarify the main factors which affect the meat quality of broilers.

\title{
Uticaj telesne mase na prinos i kvalitet mesa brojlera
}

\author{
Aleksandra Nikolić, Milijana Babić, Jelena Jovanović, Nikola Čobanović, Ivana Branković Lazić, \\ Lazar Milojević, Nenad Parunović
}

A p s t r a k t: Kvalitet mesa brojlera zavisi od interakcije velikog broja faktora, uključujući genotip, starost/telesnu masu, postupaka pre i posle klanja. Cilj ovog ispitivanja bio je da se ispita uticaj telesne mase na prinos i kvalitet mesa brojlera. Istraživanje je sprovedeno na 42 brojlera, grupisanih u tri grupe: brojleri telesne mase manje od $2500 \mathrm{~g}$, brojleri telesne mase između 2500 i 3000 g i brojleri telesne mase veće od $3000 \mathrm{~g}$. Ispitivani su sledeći pokazatelji prinosa mesa: masa hladnog trupa, masa grudi pre i posle otkoštavanja, masa kože i kostiju grudi, masa karabataka pre i posle otkoštavanja, masa kože i kostiju karabataka, masa bataka pre i posle otkoštavanja i masa kože i kostiju bataka. Od pokazatelja kvaliteta mesa određivani su pH vrednost grudne muskulature, instrumentalno $\left(L^{*}, a^{*} i b^{*}\right)$ boja grudne muskulature, karabataka i bataka 24 časa nakon klanja. Meso brojlera je razvrstavano u klase kvaliteta (bledo, meko, vodenasto - BMV i meso normalnog kvaliteta) na osnovu $L^{*}$ vrednosti instrumentalno određene boje u M. pectoralis major. Brojleri velike telesne mase imali su veću masu hladnog trupa, kao i veću masu grudi, karabataka i bataka u poređenju sa brojlerima iz druge dve grupe. Nije utvrđen uticaj telesne mase na pokazatelje kvaliteta mesa brojlera. Stoga se može zaključiti da se klanjem brojlera velike telesne mase dobija najveći prinos mesa što predstavlja dobru sirovinu za dalju preradu. Sa druge strane, utvrđen je zanemarljiv uticaj telesne mase na kvalitet mesa brojlera.

Ključne reči: teži brojleri, prinos mesa, kvalitet mesa, boja mesa.

Disclosure statement: No potential conflict of interest was reported by authors.

Acknowledgment: This work was supported by the Ministry of Education, Science and Technological Development, Republic of Serbia, Projects No. 31034, No. 31071 and No. III 46009. 


\section{References}

Abdullah, A. Y. \& Matarneh, S. K. (2010). Broiler performance and the effects of carcass weight, broiler sex, and postchill carcass aging duration on breast fillet quality characteristics. Journal of Applied Poultry Research, 19 (1), 46-58

Adzitey, F. \& Nurul, H. (2011). Pale soft exudative (PSE) and dark firm dry (DFD) meats: causes and measures to reduce these incidences-a mini review. International Food Research Journal, 18 (1), 11-20.

Baéza, E., Arnould, C., Jlali, M., Chartrin, P., Gigaud, V., Mercerand, F., Durand, C., Méteau, K., Le Bihanduval, E. \& Berri, C. (2012). Influence of increasing slaughter age of chickens on meat quality, welfare, and technical and economic results. Journal of Animal Science, 90, 2003-2013.

Barbut, B., Sosnicki, A. A., Lonergan, S. M., Knapp, T., Ciobanu, D. C., Gatcliffe, L. J., Huff-Lonergan, E. \& Wilson, E.W. (2008). Progress in reducing the pale, soft and exudative (PSE) problem in pork and poultry meat. Meat Science, 79, 46-63.

Bianchi, M., Petracci, M., Sirri, F., Folegatti, E., Franchini, A. \& Meluzi, A. (2007). The influence of the season and market class of broiler chickens on breast meat quality traits. Poultry Science, 86, 959-963.

Brake, J., Havenstein, G. B., Scheidele, S. E., Perket, P. R \& Rives, D.V. (1993). Relationship of sex, age, and body weight to broiler carcass yield and offal production. Poultry Science, 72, 1137-1145.

Cahaner, A., Nitsan, Z. \& Nir, I. (1986). Weight and fat content of adipose and non-adipose tissues in broilers selected for and against abdominal fat. Poultry Science Journal, 56, 215-222.

Carvalho, R. H., Soares, A. L., Honorato, D. C., Guarnieri, P. D., Pedrão, M. R., Paião, F. G., Oba, A., Ida, E. I. \& Shimokomaki, M. (2014). The incidence of pale, soft, and exudative (PSE) turkey meat at a Brazilian commercial plant and the functional properties in its meat product. LWT - Food Science and Technology, 59, 883-888.

CIE. (1976). International Commission on Illumination, Colorimetry: Official Recommendation of the International Commission on Illumination Publication CIE No. (E1.31). Paris, France: Bureau Central de la CIE.

Cobanovic, N., Jamnikar-Ciglenecki, U., Kirbis, A., Krizman, M., Stukelj, M. \& Karabasil, N. (2019). Impact of various housing conditions on the occurrence of pathological lesions in slaughtered pigs. Veterinarski Glasnik, 73 (1), 17-29.

Deshani, S. K., Dinesh, D. J. \& Cheorun, J. (2016). Prevalence of pale, soft, and exudative (PSE) condition in chicken meat used for commercial meat processing and its effect on roasted chicken breast. Journal of Animal Science and Technology, 58 27-41.

Eltrafi, A. S. E. M. (2006). Effect of strain and carcass weight on broiler cut's yield and characteristics. A dissertation submitted to the University of Khartoum in partial fulfillment for the requirement of the master degree of science in Poultry Production.
Fraqueza, M. J., Cardoso, A. S., Ferreira, M. C. \& Barreto, A. S. (2006). Incidence of Pectoralis major turkey muscles with light and dark color in a Portuguese slaughterhouse. Poultry Science, 85, 1992-2000.

Glamoclija, N., Starcevic, M., Ivanovic, J., Janjic, J., Boskovic, M., Djordjevic, J., Markovic, R. \& Baltic, M. Z. (2017). Comparative analysis of meat chemical composition of different broiler provenances. Meat Technology, $57(1), 1-5$.

Janisch, S., Krischek, C. \& Wicke, M. (2011). Color values and other meat quality characteristics of breast muscles collected from 3 broiler genetic lines slaughtered at 2 ages. Poultry Science, 90, 1774-1781.

Karunanayaka, D. S., Jayasena, D. D. \& Jo, C. (2016). Prevalence of pale, soft, and exudative (PSE) condition in chicken meat used for commercial meat processing and its effect on roasted chicken breast. Journal of Animal Science and Technology, 58 (1), 27-39.

Langer, R., Simoes, G. S., Soares, A. L., Oba, A., Rossa, A., Shimokomaki, M. \& Ida, E. I. (2010). Broiler transportation conditions in a Brazilian commercial line and the occurrence of breast PSE (Pale, Soft, Exudative) meat and DFD-like (Dark, Firm, Dry) meat. Brazilian Archives of Biology and Technology, 53, 1161-1167.

Lu, Q., Wen, J. \& Zhang, H. (2007). Effect of chronic heat exposure on fat deposition and meat quality in two genetic types of chicken. Poultry Science, 86, 1059-1064.

Massimiliano, P. \& Claudio, C. (2012). Muscle growth and poultry meat quality issues. Nutrients Journal, 4, 1-12.

Oba, A., Almeida, M. D., Pinheiro, J. W., Ida, E. I., Marchi, D. F., Soares, A. L. \& Shimokomaki M. (2009). The effect of management of transport and lairage conditions on broiler chicken breast meat quality and DOA (Death on Arrival). Brazilian Archives of Biology and Technology, $52,205-11$.

Omojola, A. B., Adesehinwa, A. O. K., Madu H. \& Attah S. (2004). Effect of sex and slaughter weight on broiler chicken carcass. Journal of Food, Agriculture \& Environment, 2, $61-63$.

Raseta, M., Brankovic-Lazic, I., Mrdovic, B. \& Beckei, Z. (2017). Determination of weight loss and temperature of broiler carcasses during air cooling with intermittent water spraying - case study. Meat Technology, 58 (2), 88-92.

Renema, R. A, Robinson, F. E., Newcombe, M. \& McKay, R. I. (1999). Effects of body weight and feed allocation during sexual maturation in broiler breeder hens. 1 . Growth and carcass characteristics. Poultry Science, 78, 619-628.

Simoes, G. S., Oba, A., Matsuo, T., Rossa, A., Shimokomaki, M. \& Ida, E. I. (2009). Vehicle thermal microclimate evaluation during Brazilian summer broiler transport and the occurrence of PSE (Pale, Soft, Exudative) meat. Brazilian Archives of Biology and Technology, 52, 205-11.

Toldrá, F \& Reig, M. (2011). Innovations for healthier processed meats. Trends in Food Science \& Technology, 22, $517-522$. 
Warris, P. (2010). Effect of live animal handling on carcass and meat quality. In Meat Science: An introductory text. Cambridge University Press, Cambridge, UK, $97-112$.

Yalçin, S. \& Güler, H. C. (2012). Effects of transport distance on blood metabolites and breast meat quality of broilers

Paper received: 20.12.2018.

Paper corrected: 4.06.2019.

Paper accepted: 28.06.2019. slaughtered at different weights. British Poultry Science, $53,175-182$.

Yalçın, S., Güler, H. C., Yaşa, I., İzzetoğlu, G. T. \& Özkan, S. (2014). Effect of breeder age and slaughter weight on meat quality traits of broiler breast and leg meats. European Poultry Science, 78, 1-10. 